\title{
Analysis of Influence of Compensation and Leadership Style to Employee Performance PT. Feva Indonesia
}

\author{
Bulawambona Endah Purnamasari $^{\mathrm{a}^{*}}$, Rr. Hermien Tridayanti ${ }^{\mathrm{b}}$ \\ ${ }^{a}$ Faculty of Economics and Business, Narotama University, Surabaya, Indonesia, endahsr77@ gmail.com \\ ${ }^{a}$ Faculty of Economics and Business, Narotama University, Surabaya, Indonesia, hermien.tridayanti@narotama.ac.id
}

\begin{abstract}
The purpose of this study is to study leadership style and comparison of employee performance. This research was conducted at the company PT. Feva Indonesia. The population used was 60 people. Data collection is done through interviews. The analytical tool used is multiple linear regression techniques. The results of the analysis show a positive leadership style but not significant on employee performance. This shows how leadership style is not related or not significant to employee performance, related to employee performance that requires authoritarian support and cannot be involved in the decision making process. Positive and significant compensation variables on employee performance. This shows that fair and proper assistance is needed to be given to employees, the employee's needs will increase significantly.
\end{abstract}

Keywords: Compensation, Leadership style, Employee performance

\section{Introduction}

Human resources are the driving force of an organization, which is considered as an asset of the company so that it must be trained and developed its capabilities. Human resources is a thing that must be had in an effort to achieve the goals and targets of a company or organization. Human resources have also become an indispensable element related to the goals and expectations of the company towards the future.

Human resources are increasingly advanced to make the company also have to think about how to maximize performance owned by employees, for that we can develop in various ways both training and development in terms of skills in order to achieve the demands of the organization for the progress of the company. Various things that need to be done on human resources, no less important are also things as simple as work timeliness and work effectiveness in an organization. Behind it all, there are some things that can spur it like giving compensation as an appreciation of employee performance.

Factors that influence employee performance are the work environment, work responsibilities, leadership work methods and compensation.

The work environment is related to how comfortable and complete the facilities the company has in order to support employee productivity. Work responsibilities, this can affect performance because these responsibilities become benchmarks against compensation to be received. Not infrequently many employees who have a lot of work responsibilities but are not matched with appropriate rewards.

Leadership style, with direct contact between employees and superiors, makes this leadership style a thing that can affect performance. The leadership style that is less comfortable makes the employee's sympathy will decrease towards the boss and this will obviously greatly affect the employee's performance. Compensation, a reward that will surely be received by all employees who work, compensation is often considered as a company's appreciation of employees for all their participation in the company, but compensation can also be a trigger on performance because

\footnotetext{
* Corresponding author.

E-mail address: endahsr77@gmail.com (Bulawambona Endah Purnamasari)
} 
with the imbalance between rewards and workload can be an employee enthusiastic and not optimal on its performance.

According to Thoha (2013) that Leadership Style is the norm of behavior used by someone when the person is trying to influence the behavior of others as he sees it.

PT. Feva Indonesia which is engaged in road construction whose office is located at the Galaxi Bumi Permai M2 block No. 7 Surabaya. The problems that exist in PT. Feva Indonesia at this time, namely the influence of leadership style and the compensation received turned out to make performance at PT. Indonesian Feva is declining. Some of the underlying reasons are the imbalance of compensation with work responsibilities and leadership style which makes several reasons for employees to be absent from the company.

We can draw the diagram above from the conclusion that the amount of employee turnover is very influential on PT Feva Indonesia. This has an impact on the performance of employees who are at PT. Feva Indonesia, uneven performance and productivity in several departments occurs due to compensation and incompatibility with the leadership style of superiors, which can be proven by the results of the questionnaire given by the HRD department.

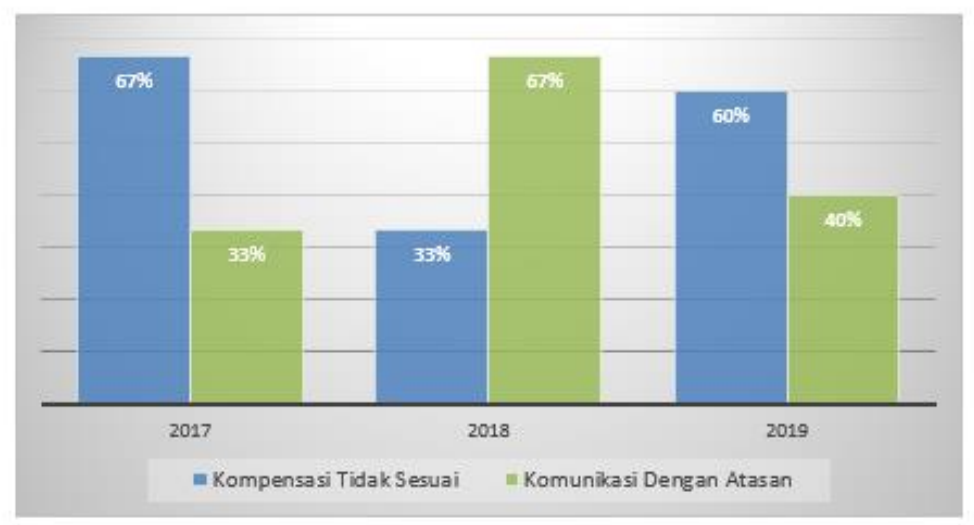

Figure 1 Percentage of Cause of Absent Employees Periode of 2017-2019 (in Indonesia)

Based on the results of the data above related to the phenomenon of compensation and leadership styles that occur at PT Feva Indonesia by linking it to the performance of PT Feva Indonesia's employees, the title of this research is "Analysis of the Effects of Compensation and Leadership Style on Performance at PT. Feva Indonesia Surabaya ".

\section{Theoretical basis}

\subsection{Compensation}

Compensation is the total of all gifts given by the organization to employees in return for their services. According to Hasibuan (2012: 118) said compensation is all income in the form of money, direct or indirect goods received by employees in return for services provided to the company. One of the purposes of providing compensation is to provide adequate compensation as an appreciation of work performance.

Compensation itself can be divided into 2 large groups, namely:

1. Compensation based on its form, consisting of:

a. Financial compensation is compensation given in the form of objects, such as the provision of salaries, incentives, operational vehicles and office facilities.

b. Non-financial compensation is compensation given in the form of satisfaction, or appreciation without the form. Like giving praise as motivation for the success of the target in the work done.

2. Compensation based on how it is given, consisting of 
a. Direct financial compensation that refers to compensation given in the form of objects such as wages, bonuses or commissions.

b. Indirect financial compensation is compensation given in the form of benefits, including: insurance and leave.

\subsection{Leadership Style}

The leadership style can be defined as an overall pattern of the actions of a leader both related to subordinates and with work recap. This leadership style also involves the attitude, nature, consistency and skills of a leader.

Thoha (2013) explains that Leadership Style is the norm of behavior used by a person when that person tries to influence the behavior of others as he sees it.

A leader must have a different way or leadership style to attract the attention and interest of employees to work according to the direction and wishes of a leader. Here are 3 leadership styles based on the type according to Hasibuan (2016: 172):

1. Authoritarian leadership is power or authority, most of which is absolutely in the leadership if the leader follows a centralized system of authority. Decision making and policy are only determined solely by the leader, subordinates are not included to provide suggestions, ideas, and considerations in the decision making process.

2. Delegative Leadership is a leader who delegates authority to subordinates rather completely. Thus subordinates can take decisions and wisdom freely or freely in carrying out their work. Leaders do not care about how subordinates make decisions and do their work, fully left to subordinates.

3. Participative leadership is if the leadership is carried out in a persuasive way, creating harmonious cooperation, fostering loyalty, and participation of subordinates. The leader will encourage the ability of subordinates to make decisions.

\subsection{Employee performance}

A company that is founded must have each goal with patented targets to be achieved. And to achieve these goals is strongly supported by behavior in the organization, which is related to how much the potential of employees to achieve targets to advance the company.

This is what will drive maximization in performance in order to achieve these things. Understanding performance is an illustration of how much the ability of employees to complete the responsibilities, vision, mission and goals of the company which are outlined in the work strategy.

According to John Minner (2015: 8) said that performance is the productivity relationship between the amount of goods and services produced in the amount of labor, capital and resources used in the production.

\subsection{Performance Factors}

An employee's performance must be covered by things that encourage performance, both in terms of improving performance, or poorly or by making performance decrease. Performance factors can be divided into 3 namely:

1. Individual compensation: the ability and skills to do work.

2. Organizational Support Factors: factors that provide employees a sense of comfort in the work environment, support like this can improve performance easily, because employees feel the work environment is very supportive with the workload received.

3. Psychological Factors: The company is important to know the performance of employees in order to take steps to develop existing human resources in the company by involving employees in activities such as training. 


\subsection{Conceptual framework}

Based on the background of the problem, the formulation of the problem and the theoretical basis as described above, the conceptual framework in this study is as follows:

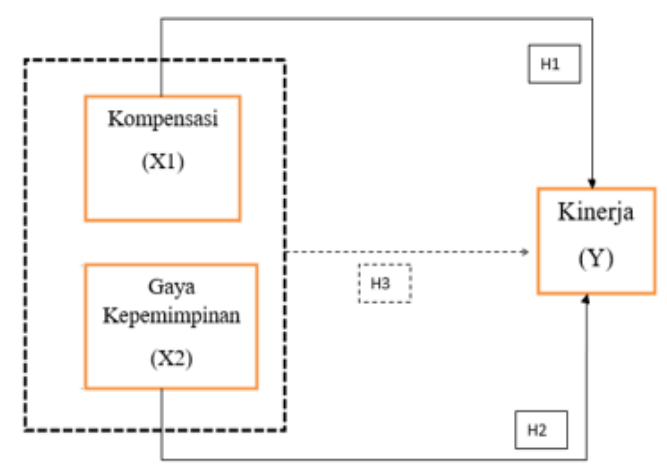

Figure 2 Conceptual framework (in Indonesia)

\subsection{Hypothesis}

Based on the research objectives, theoretical basis and conceptual framework as described above, the hypotheses in this study are as follows:

a. H1: Compensation has a significant effect on employee performance

b. H2: Leadership style significantly influences employee performance

c. H3: There is a significant influence between compensation and leadership style on employee performance

\section{Research method}

\subsection{Research Approach}

The research approach was carried out using a quantitative approach through a questionnaire method. According to Sugiyono (2017: 142) the questionnaire is a data collection technique that is done by giving a set of questions or written statements to respondents to answer. This study will find out the relationship between compensation and leadership style on employee performance at PT. FEVA INDONESIA

\subsection{Population}

Population is a generalization area consisting of objects / subjects that have certain qualities and characteristics determined by researchers to be studied and then drawn conclusions (Sugioyono, 2017: 80). The population in this study were all employees of PT. FEVA INDONESIA, amounting to 60 people.

\subsection{Sample}

According to Sugiyono (2017: 81) the sample is part of the number and characteristics possessed by the population. The sampling technique uses a questionnaire. Questionnaire is an information gathering technique that allows analysts to learn attitudes, beliefs, behavior, and characteristics of several key people in the organization who can be 
affected by the proposed system or by an existing system. So the number of samples in this study were 60 employees of PT. FEVA INDONESIA.

\subsection{Data Type}

According to Sugiyono (2015) research data sources can be divided into 2, namely primary data sources and secondary data sources. The type of data used in this study is:

a. Primary Data: data sources that directly provide data to data collectors (Sugiyono, 2015). Primary data were obtained from distributing questionnaires to PT Feva Indonesia employees who were willing to become respondents and fill out the questionnaire.

b. Secondary Data: data sources that do not directly provide data to data collectors, for example through documents or other people. The secondary data of this study is the turnover list of PT Feva Indonesia and the percentage of defaulters obtained from the HRD Department at PT Feva Indonesia

\subsection{Data source}

To support maximum results in this study, researchers conducted data collection in the following way:

a. Field Research

Research carried out by going directly to the field for obtain data relating to the problem discussed.

b. Observation

Observation is one method of collecting data by observing or observing carefully and directly at the research location or field to know firsthand the conditions that occur or to prove the truth of a research design

c. Questionnaire

Questionnaire is a possible information collection technique. The analysis studies the attitudes, beliefs, behaviors, and characteristics some of the main people in the organization

d. Interview

Interview is a form of oral communication that is done in a manner structured by two or more people, both directly and distance far, to discuss and explore certain information in order to achieve the goal certain.

e. Literature research

Literature research is a data collection technique by studying various books, literature, notes, and various reports relating to the problem to be solved

\subsection{Variable}

The research variable is an attribute or nature or value of people, objects or activities that have certain variations that are determined by researchers to be studied and then drawn conclusions (Sugiyono, 2017: 39). Variables are divided into 2, namely: Independent variables (independent variables) and dependent variables (dependent variables).

a. The independent variable (independent variable), is a variable that influences or causes the change or emergence of the dependent variable. The independent variables in this study are Compensation (X1) and Leadership Style (X2)

b. Dependent variable (dependent variable) is a variable that is affected or that is due, because of the independent variable. The dependent variable in this study is Employee Performance (Y).

\subsection{Data analysis technique}

Data analysis is one of the research activities in the form of data preparation and processing in order to interpret the data that has been obtained. 


\subsubsection{Validity test}

From the testing criteria if the correlation between items with a total score of more than 0.3 then the instrument is declared valid or vice versa if the correlation between items is less than the score of 0.3 then the instrument is declared invalid. If $r$ count $>\mathrm{r}$ table with $\alpha=0.05$, the correlation coefficient is significant.

\subsubsection{Reliability Test}

The reliability test is an index that shows the extent to which the measurement tool can be trusted. To achieve this, a reliability test was conducted using SPSS with the Cronbach's Alpha model which was measured based on the Cronbach's alpha scale 0 to 1 .

\subsubsection{Normality test}

According to Ernawati (2015) the data normality test is carried out to find out whether the data is normally distributed or not.

According to Singgih Santoso (2016: 393), the basic basis of decision making can be done based on probabilities (Asymtotic Significant), namely:

a. If Probability> 0.05 then the distribution of the population is normal.

b. If Probability $<0.05$ then the population is not normally distributed. Visual testing can also be done using the normal probability plots graph method in the basic SPSS program for decision making

c. If the data spreads around the diagonal line and follows the direction of the diagonal line, it can be concluded that the regression meets the assumption of normality.

d. If the data spreads far from the line and does not follow the direction of the diagonal line, it can be concluded that the regression model does not meet the assumption of normality.

\subsubsection{Multicollinearity Test}

Multicorlinearity is a situation where some or all independent variables are highly correlated.

Thus it means that the greater the correlation between the independent variables, the regression coefficients the greater the error, the greater the standard error.

\subsubsection{Heteroscedasticity Test}

This test is used to determine whether the variable storage regression model is uncertain or not. As for detecting the existence of heteroscedasticity that is by looking at the presence or absence of certain patterns on the scatterplot graph. (Singgih Santoso, 2016: 210). If the probability is> alpha (0.05), then it is certain that the model does not contain heteroscedasticity. If the probability of the result is less than 0.05 then the regression equation contains heteroscedasticity.

\subsection{6. $\quad$ Multiple Linear Regression Analysis}

According to Sugiyono (2015: 277) multiple linear regression analysis is a multiple linear regression analysis used by researchers, if the researcher intends to predict how the state (ups and downs) of the dependent variable (criterium), if two or more independent variables as predictor factors are manipulated (increased in value).

Multiple linear regression analysis was used in this study with the aim to prove the hypothesis about the influence of the variable Compensation (X1), Leadership Style (X2) partially or simultaneously on Employee Performance (Y). 


\subsection{7. $\quad$ F test}

Aims to determine the feasibility of multiple linear regression models as an analytical tool that tests the effect of independent variables (independent) on the dependent variable (bound) together. When $\mathrm{F}$ counts $<\mathrm{F}$ table. Then $\mathrm{H} 0$ is accepted and $\mathrm{Ha}$ is rejected, meaning there is no simultyan influence. If $\mathrm{F}$ arithmetic $>\mathrm{F}$ table then $\mathrm{H} 0$ is rejected and $\mathrm{Ha}$ is accepted, meaning there is a simultaneous influence

\subsection{8. $\quad$ T test}

The $\mathrm{T}$ test is a regression coefficient test used to find out whether the independent variable $(\mathrm{X})$ individually influences the dependent variable (Y).

\section{Result and Discussion}

\subsection{Description of Research Results}

As already stated that the subjects of this study are employees of PT. Feva Indonesia having their address at Galaxi bumi permai M2 no 7 Surabaya. The questionnaire used in this study amounted to 60 respondents. This questionnaire was given directly to respondents.

\subsection{Gender of Respondences}

\begin{tabular}{|c|c|c|c|c|c|}
\hline & & Frequency & Percent & Valid Percent & $\begin{array}{c}\text { Cumulative } \\
\text { Percent }\end{array}$ \\
\hline Valid & $\begin{array}{l}\text { Laki-Laki } \\
\text { Perempuan } \\
\text { Total }\end{array}$ & $\begin{array}{l}39 \\
21 \\
60\end{array}$ & $\begin{array}{r}65.0 \\
35.0 \\
100.0\end{array}$ & $\begin{array}{r}65.0 \\
35.0 \\
100.0\end{array}$ & $\begin{array}{r}65.0 \\
100.0\end{array}$ \\
\hline
\end{tabular}

Figure 3 Descriptif of Gender of respondences

Based on the figure 3, it can be seen that the characteristics of respondents based on the sex of PT Feva Indonesia's employees at Galaxi Bumi Permai M2 no 7, namely 39 men (65\%) and the number of female respondents is 21 people (35\%). This shows that most of the employees at PT Feva Indonesia are male.

\subsection{Education of Respondents}

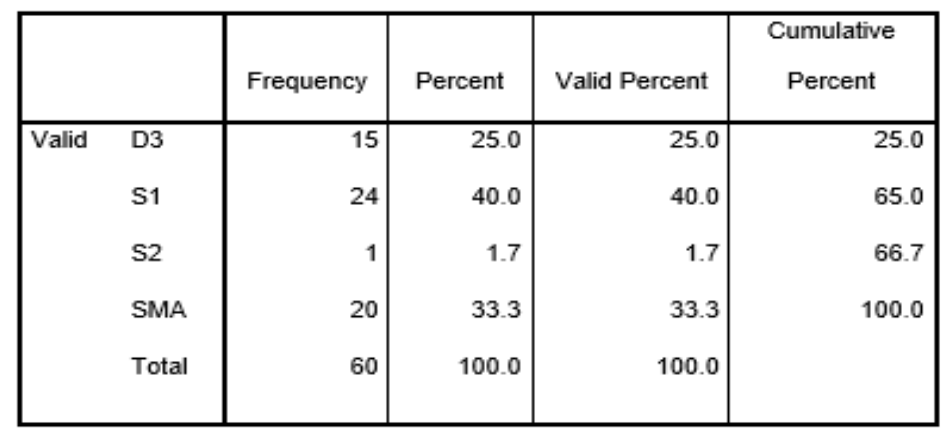

Figure 4 Descriptif of Education of respondences 
Based on the figure 4, it can be seen that the characteristics of respondents based on the education of PT Feva Indonesia employees at Galaxi Bumi Permai M2 no 7, namely D3 by 15 people (25\%), S1 by 24 people (40\%), S2 by 1 person (1.7\%) and high school as many as 20 people (33.3\%). This shows that most of the employees at PT Feva Indonesia are S1 educated.

\subsection{Age of Respondents}

Based on the figure 5, it can be seen that the characteristics of respondents based on the age of PT Feva Indonesia's employees at Galaxi Bumi Permai M2 no 7, namely Age 25-30 years as many as 35 people (58.3\%), Ages 20-25 years as many as 15 people (25\%) and Age over from 30 years (16.7\%). This shows that most of the employees at PT Feva Indonesia are aged 25-30 years.

\begin{tabular}{|c|c|c|c|c|c|}
\hline & & Frequency & Percent & Valid Percent & $\begin{array}{c}\text { Cumulative } \\
\text { Percent }\end{array}$ \\
\hline \multirow[t]{4}{*}{ Valid } & $>30$ & 10 & 16.7 & 16.7 & 16.7 \\
\hline & $20-25$ & 15 & 25.0 & 25.0 & 41.7 \\
\hline & $25-30$ & 35 & 58.3 & 58.3 & 100.0 \\
\hline & Total & 60 & 100.0 & 100.0 & \\
\hline
\end{tabular}

Figure 5 Descriptif of Age of respondences

\subsection{Long time the respondent worked}

Information about the length of work is very important information in this study. The age of the respondent will influence knowledge and thoughts in providing answers / filling in the questionnaire. The figure 6 presents the distribution of respondents by age.

\begin{tabular}{|rl|r|r|r|r|}
\hline & Frequency & Percent & Valid Percent & $\begin{array}{c}\text { Cumulative } \\
\text { Percent }\end{array}$ \\
\hline Valid & $>5$ & 3 & 5.0 & 5.0 & 5.0 \\
& $1-3$ & 45 & 75.0 & 75.0 & 80.0 \\
$4-5$ & 12 & 20.0 & 20.0 & 100.0 \\
& Total & 60 & 100.0 & 100.0 & \\
\hline
\end{tabular}

Figure 6 Distribution of age of respondences

\subsection{Reliability Test}

According to Sugiono (2014: 121) Reliability is an instrument that if used several times to measure the same object, will produce the same data. Reabilitation test is carried out with the help of Cronbach's SPSS (a) a variable is said to be reliable if it has a Cronbach alpha> 0.60 . Then it can be seen in figure 7 . 


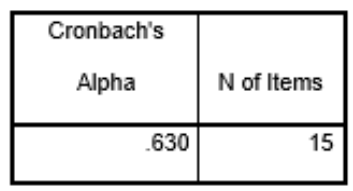

Figure 7 Result of reliability test

From figure 7, it can be seen, this research data has Cronbach alpha 0.630 and is greater than 0.60 , then this research data can be stated reliable and reliable.

\subsection{Validity test}

To get the data, questionnaires were distributed to respondents, namely PT Feva Indonesia employees with address at Galaxi Bumi Permai M2 No. 7 Surabaya as many as 60 respondents, of which 60 people will act as representatives of all employees of PT Feva Indonesia. The data obtained must be accurate and objective so it is necessary to know how high the reliability and validity of the questionnaire used.

According to Saifuddin Azwar (2014) validity refers to the extent of the accuracy of a test or scale in carrying out its measurement function. If it is greater than or equal to 0.25 (distribution value Sig. 5\%) then the statement is considered valid. As shown in the SPSS output for the compensation variable (X1), the leadership style variable (X2) and the Performance variable (Y) in figure 8.

\begin{tabular}{|c|r|r|c|}
\hline Pernyataan & \multicolumn{1}{|c|}{ Koefisien } & \multicolumn{1}{c|}{ Batas } & Keterangan \\
& Korelasi & Minimum & \\
\hline $\mathrm{X} 1.1$ & 0.701 & 0.25 & VALID \\
\hline $\mathrm{X} 1.2$ & 0.110 & 0.25 & VALID \\
\hline $\mathrm{X} 1.3$ & 0.435 & 0.25 & VALID \\
\hline $\mathrm{X} 1.4$ & 0.751 & 0.25 & VALID \\
\hline $\mathrm{X} 1.5$ & 0.546 & 0.25 & VALID \\
\hline $\mathrm{X} 1.6$ & 0.753 & 0.25 & VALID \\
\hline $\mathrm{X} 1.7$ & 0.754 & 0.25 & VALID \\
\hline $\mathrm{X} 1.8$ & 0.618 & 0.25 & VALID \\
\hline
\end{tabular}

Figure 8 SPSS output for the compensation variable (X1) (in Indonesia)

From figure 8 , it can be seen that for the compensation variable statement item (X1) is valid because the correlation level > 0.25. Further testing of the item statement of leadership style variables (X2) can be seen in figure 9 . 


\begin{tabular}{|c|r|r|c|}
\hline Pernyataan & $\begin{array}{c}\text { Koefisien } \\
\text { Korelasi }\end{array}$ & $\begin{array}{c}\text { Batas } \\
\text { Minimum }\end{array}$ & Keterangan \\
\hline $\mathrm{X} 2.1$ & 0.285 & 0.25 & VALID \\
\hline $\mathrm{X} 2.2$ & 0.746 & 0.25 & VALID \\
\hline $\mathrm{X} 2.3$ & 0.773 & 0.25 & VALID \\
\hline
\end{tabular}

Figure 9 SPSS output for the leadership style variable (X2) (in Indonesia)

From figure 9, it can be seen that for the item statement of leadership style variable (X2) is valid because the correlation level> 0.25. Furthermore, testing the Performance variable statement item (Y) can be seen as follows:

\begin{tabular}{|c|r|r|c|}
\hline Pernyataan & Koefisien & \multicolumn{1}{c|}{ Batas } & Keterangan \\
Korelasi & Minimum & \\
\hline Y1.1 & 0.876 & 0.25 & VALID \\
\hline Y1.2 & 0.714 & 0.25 & VALID \\
\hline Y1.3 & 0.706 & 0.25 & VALID \\
\hline Y1.4 & 0.523 & 0.25 & VALID \\
\hline
\end{tabular}

Figure 10 SPSS output for the Performance variable (Y) (in Indonesia)

From figure 10, it can be seen that for statement items the performance variable $(\mathrm{Y})$ is valid because the correlation level>0.25.

\subsection{Normal Distribution Test}

Normal distribution test is a test conducted for the prerequisites of a data analysis. This test is carried out before the data is processed based on a model that will be submitted. Normality test aims to analyze data in one variable that will be used in a study. The normality test used is the Kolmogorov-Smirnov test. The data will be said to be normal, if the significant value is greater than 0.05 at $(\mathrm{p}>0.05)$.

\section{One-Sample Kolmogorov-Smirnov Test}

\begin{tabular}{|ll|r|}
\hline & & $\begin{array}{r}\text { Unstandardiz } \\
\text { ed Residual }\end{array}$ \\
\hline $\mathrm{N}$ & Mean & 60 \\
Normal Parameters $\mathrm{a}, \mathrm{b}$ & .0000000 \\
& Std. Deviation & 1.54141135 \\
Most Extreme Differences & Absolute & .145 \\
& Positive & .145 \\
& Negative & -.090 \\
Kolmogorov-Smirnov $Z$ & & 1.126 \\
Asymp. Sig. (2-tailed) & & .158 \\
\hline
\end{tabular}

a. Test distribution is Normal.

b. Calculated from data.

Figure 11 Result of Kolmogorov-Smirnov test 
From figure 11 shows that the significance value of Asymp Sig (2-tailed) of 0.158 is greater than 0.05 . So according to the basis of decision making in the Kolmogorov-Smirnov normality test above, it can be concluded that the data are normally distributed. Thus, the assumptions or normality requirements in the regression model have been fulfilled.

\subsection{Multiple Linear Regression Equations}

Multiple linear regression analysis was used in this study with the aim to prove the hypothesis about the influence of the variable Compensation (X1), Leadership Style (X2) partially or simultaneously on Employee Performance (Y). A summary of data management using SPSS in this study is shown in figure 12.

\begin{tabular}{|c|c|c|c|c|c|}
\hline \multicolumn{6}{|c|}{ Coefficients ${ }^{3}$} \\
\hline \multirow[t]{2}{*}{ Model } & \multicolumn{2}{|c|}{ Unstandardized Coefficients } & \multirow{2}{*}{$\begin{array}{c}\begin{array}{c}\text { Standardized } \\
\text { Coefficients }\end{array} \\
\text { Beta }\end{array}$} & \multirow[b]{2}{*}{$t$} & \multirow[b]{2}{*}{ Sig. } \\
\hline & B & Std. Error & & & \\
\hline (Constant) & 1.588 & 1.872 & & .849 & .400 \\
\hline Kompensasi $(X 1)$ & .279 & .053 & .600 & 5.283 & .000 \\
\hline Gaya Kepemimpinan $(\alpha 2)$ & .184 & .135 & .155 & 1.364 & .178 \\
\hline
\end{tabular}

a. Dependent Variable: Kineria $(n)$

Figure 12 Result of multiple linerar regression analysis

\subsection{R Square Determination Test and Adjusted R Square}

The coefficient of determination (R2) is used to determine how far the model's ability to explain the variation of the dependent variable. The greater the value of the coefficient of determination means the greater the ability of the independent variable in explaining the dependent variable.

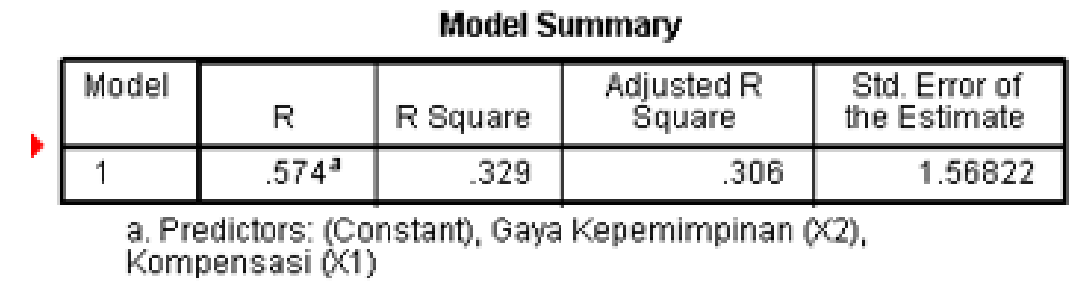

Figure 13 Model summury of multiple linerar regression analysis

Based on the output in figure 13, it is known that the coefficient of determination or R Square is 0.574 which is $0.574 \times 0.574=0.329$. The magnitude of the coefficient of determination (R Square) is 0.329 or equal to $32.9 \%$. This figure implies that the compensation variable (X1) and leadership style (X2) simulatively affect the performance variable $(\mathrm{Y})$ of $32.9 \%$. While the rest $(100 \%-32.9 \%=67.1 \%)$ is influenced by other variables outside this regression equation or variables not examined.

\subsection{F Test (Simultaneous Test)}

Aims to determine the feasibility of multiple linear regression models as an analytical tool that tests the effect of independent variables (independent) on the dependent variable (bound) together. When $\mathrm{F}$ counts $<\mathrm{F}$ table. Then $\mathrm{H} 0$ is accepted and $\mathrm{Ha}$ is rejected, meaning there is no simultyan influence. If $\mathrm{F}$ arithmetic $>\mathrm{F}$ table then $\mathrm{H} 0$ is rejected and $\mathrm{Ha}$ accepted means that there is influence simultaneously. 


\begin{tabular}{|c|c|c|c|c|c|}
\hline \multicolumn{6}{|c|}{ ANOVA ${ }^{b}$} \\
\hline & $\begin{array}{c}\text { Sum of } \\
\text { Squares }\end{array}$ & df & Mean Square & $\mathrm{F}$ & Sig. \\
\hline Regression & 68.752 & 2 & 34.376 & 13.978 & $.000^{4}$ \\
\hline Residual & 140.181 & 57 & 2.459 & & \\
\hline Total & 208.933 & 59 & & & \\
\hline
\end{tabular}

Figure 14 Result of ANOVA

Based on the figure 14, it is known that the significance value (Sig) in the F test is 0,000 . Because Sig. $0.000<0.05$, then as the basis for decision making in the F test it can be concluded that Compensation (X1) and Leadership Style (X2) simultaneously affect Performance (Y) or significant means. Thus, the requirements so that we can interpret the value of the coefficient of determination in multiple linear analysis has been fulfilled

\subsection{T Test (Partial Test)}

The $\mathrm{T}$ test is a regression coefficient test used to find out whether the independent variable $(\mathrm{X})$ individually influences the dependent variable (Y).

\begin{tabular}{|c|c|c|c|c|c|}
\hline \multicolumn{6}{|c|}{ Coefficients ${ }^{3}$} \\
\hline \multirow[t]{2}{*}{ Model } & \multicolumn{2}{|c|}{ Unstandardized Coefficients } & \multirow{2}{*}{$\begin{array}{c}\text { Standardized } \\
\text { Coefficients } \\
\text { Beta }\end{array}$} & \multirow[b]{2}{*}{$t$} & \multirow[b]{2}{*}{ Sig. } \\
\hline & $B$ & Std. Error & & & \\
\hline (Constant) & 1.588 & 1.872 & & .849 & .400 \\
\hline Kompensasi $(X 1)$ & .279 & .053 & .600 & 5.283 & .000 \\
\hline Gara Kepemimpinan $(\alpha 2)$ & .184 & .135 & .155 & 1.364 & .178 \\
\hline
\end{tabular}

Figure 15 Result of T test

H1: Compensation has a significant effect on employee performance

H2: Leadership style significantly influences employee performance

1. Based on the SPSS output in figure 15, it is known that the value of t_count is 5.283 with a Significant value (Sig.) Of the Compensation variable (X1) of 0,000 <probability 0.05 then H_0 is rejected and Ha is accepted meaning that compensation has a partially significant effect on employee performance. Thus the second hypothesis that the authors propose, "Compensation has a significant effect on Employee Performance" is proven empirically correct.

2. Based on the SPSS output in figure 15, it is known that the t-count value is 1,364 with a Significant value (Sig.) Leadership Style variable (X2) of 0.178> probability 0.05 then $\mathrm{H} \_0$ is accepted and Ha is rejected meaning that the leadership style does not have a significant effect partially on employee performance. Thus the second hypothesis that the authors propose that "Leadership Style significantly influences Employee Performance" is not proven empirically correct. This happens to have a meaning that is the influence of an authoritarian leadership style from superiors to employees has become a habit so it does not have much influence on performance, accustomed to not being involved and the lack of superiors involving employees make passive employees influence the boss's leadership style. 


\subsection{Normality Test}

According to Ernawati (2015) the data normality test is carried out to find out whether the data is normally distributed or not.

According to Singgih Santoso (2016: 393), the basic basis of decision making can be done based on probabilities (Asymtotic Significant), namely:

a. If Probability $>0.05$ then the distribution of the population is normal.

b. If Probability $<0.05$ then the population is not normally distributed. Visual testing can also be done using the normal probability plots graph method in the basic SPSS program for decision making

c. If the data spreads around the diagonal line and follows the direction of the diagonal line, it can be concluded that the regression meets the assumption of normality.

d. If the data spreads far from the line and does not follow the direction of the diagonal line, it can be concluded that the regression model does not meet the assumption of normality.

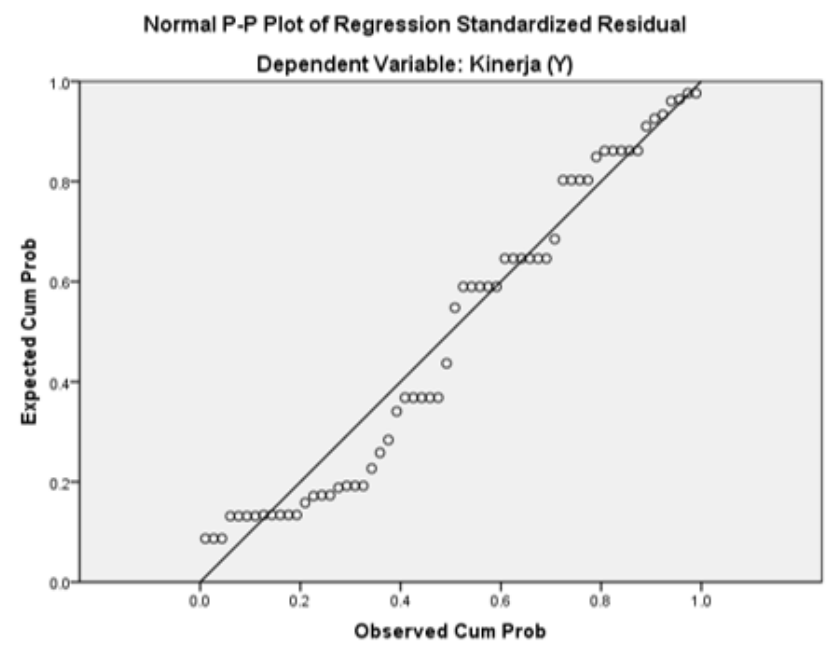

Figure 16 Result of Normality Test

Based on the figure 16, we can see that the ploting points contained in the picture "Normal PP-Plot Of Regression Standardized Residual" always follow and approach the diagonal lines. Therefore, as the basis or guidelines for decision making in the probability plot normality test, it can be concluded that the residual value is normally distributed. Thus the normality assumption for residual values in the simple linear regression analysis in this study can be fulfilled.

\subsection{Multicollinearity Test}

Multicorlinearity is a situation where some or all independent variables are highly correlated.

Thus it means that the greater the correlation between the independent variables, the regression coefficients the greater the error, the greater the standard error.

Based on the figure 17, it is known that the Tolerance value for the Compensation variable (X1) and Leadership Style (X2) is 0.911 greater than 0.10. While the VIF value for the variable Performance (X1) and Leadership Style (X2) is 1,097 smaller than 10.00. Then referring to the basis of decision making in the Multicollinearity Test it can be concluded that there are no symptoms of multicollinearity in the regression model. 


\begin{tabular}{|c|c|c|c|c|c|c|c|c|}
\hline \multicolumn{9}{|c|}{ Coefficients ${ }^{3}$} \\
\hline \multirow{2}{*}{\multicolumn{2}{|c|}{ Model }} & \multicolumn{2}{|c|}{ Unstandardiced Coefficients } & \multirow{2}{*}{$\begin{array}{c}\text { Standardized } \\
\text { Coefficients } \\
\text { Beta }\end{array}$} & \multirow[b]{2}{*}{1} & \multirow[b]{2}{*}{ Sig. } & \multicolumn{2}{|c|}{ Collinearity Statistics } \\
\hline & & 8 & Std. Error & & & & Tolerance & MF \\
\hline \multirow[t]{3}{*}{1} & (Constant) & 1.588 & 1.872 & & .849 & 400 & & \\
\hline & Kompensasi $(Q 1)$ & .279 & .053 & .600 & 5.283 & .000 & .911 & 1.097 \\
\hline & Oaya Kepemimpinan $\left(C_{2}\right)$ & .184 & .135 & .155 & 1.364 & 178 & .911 & 1.097 \\
\hline
\end{tabular}

Figure 17 Result of Multicollinearity test

\subsection{Heteroscedasticity Test}

This test is used to determine whether the variable storage regression model is uncertain or not. As for detecting the existence of heteroscedasticity that is by looking at the presence or absence of certain patterns on the scatterplot graph. (Singgih Santoso, 2016: 210). If the probability is> alpha (0.05), then it is certain that the model does not contain heteroscedasticity. If the probability of the result is less than 0.05 then the regression equation contains heteroscedasticity.

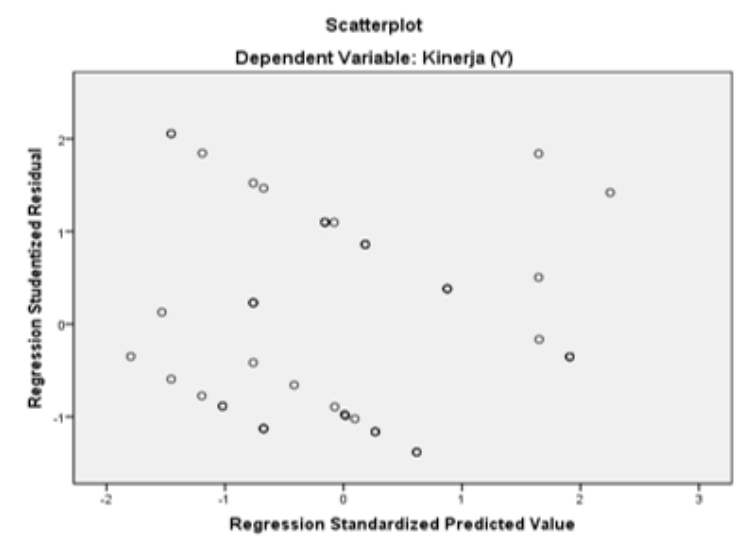

Figure 18 Result of Scatterplot

Based on the scatterplots output (figure 18), it is known that:

1. Spread data points above and below or around the number 0

2. The points do not collect only above or below

3. The spread of data points does not form a wavy pattern widened then narrowed and widened again

4. Spread of data points not patterned

Thus we can conclude that there is no heteroscedasticity problem so that good and ideal regression models can be fulfilled.

\subsection{Effect of Compensation on Employee Performance}

The results of statistical calculations show the value of $\mathrm{t}$-count of 5.283 with a Significant value (Sig.) Of the Compensation variable (X1) of 0,000 <probability 0.05 then $\mathrm{H}_{-} 0$ is rejected and Ha accepted means that compensation has a partially significant effect on employee performance. 
It can be interpreted that Compensation owned by PT Feva Indonesia has an effect on Employee Performance as indicated by the ability of employees to complete the work and workload provided to achieve the company's targets. This is proven in accordance with the opinion of Hasibuan (2012: 118) Compensation is all income in the form of money, direct or indirect goods received by employees in return for services provided to the company. One of the purposes of providing compensation is to provide adequate compensation as an appreciation of work performance.

\subsection{The Effect of Leadership Style on Employee Performance}

The results of statistical calculations show that the t-value of 1,364 with a Significant value (Sig.) Of the Leadership Style variable (X2) is $0.178>$ probability of 0.05 then $\mathrm{H} 1$ is rejected, meaning that the leadership style has no significant effect on employee performance. The influence of the authoritarian leadership style of superiors on employees has become a habit so that it does not have much influence on performance, accustomed to being excluded and the lack of superiors involving employees makes employees passive to the influence of superiors' leadership styles. According to Thoha (2013), that Leadership Style is the norm of behavior used by someone when the person is trying to influence the behavior of others as he sees it

\section{Conclusion}

Based on the analysis conducted, several conclusions can be drawn as follows:

1. Based on the analysis of the effect of compensation on employee performance the Sig. $t$ of 0,000 with a beta coefficient of 0.600. Sig value t $0,000<0.05$ indicates that $H_{-} 0$ is rejected and $H_{-} 1$ is accepted. This result means that compensation has a positive and significant effect on employee performance. This influence means that the higher the compensation, the greater the performance of employees produced against PT Feva Indonesia.

2. Based on the results of the analysis of the influence of leadership style on employee performance, the Sig. $t$ of 0.178 with a beta coefficient of 0.155 . Sig value t $0.178>0.05$ indicates that $H_{-} 1$ was rejected. This result means that the leadership style has a positive and not significant effect on employee performance. This influence has meaning namely the influence of an authoritarian leadership style from superiors to employees has become a habit so that it does not have much influence on performance, accustomed to being excluded and the lack of superiors involving employees makes employees passive to the influence of superiors' leadership styles.

\section{References}

Aslam, A., Ghaffar, A., Talha, T., \& Mushtaq, H. (2015). Impact of Compensation and Reward System on the Performance of an Organization: an Empirical Study on Banking Sector of Pakistan. European Journal of Business and Social Sciences, 4(08), 319-325. Retrieved from http://www.ejbss.com/recent.aspx-/

Fajrin, I. Q., \& Susilo, H. (2018). The Effect of Leadership Style on Employee Performance with Work Motivation as an Intervening Variable (Study on Employees of Kebon Agung Malang Sugar Factory). Journal of Business Administration, 61 (4), 117-124.

Ilmawan, M. D., Wulandari, D. S., \& Fitriani, F. (2017). The Role of Leadership Style and Compensation in Affecting Performance Mediated by Job Satisfaction.

Journal of Modernization Economics, 13 (1), 37. https://doi.org/10.21067/jem.v13i1.1745

Leadership You Need to Know "2017. https://www.finansialku.com/style-manship-in-organizations-storiesleadership/

Kompas.com. "7 Conditions to Be a Leader" .2008. https://nasional.kompas.com/read/2008/03/11/18010525/7.squis.jadi.pel leaders

Maulina Rishna. "The Purpose and Benefits of Providing Employee Compensation at the Company." 2019. https://sleekr.co/blog/target-dan-ben-kompensation-karyawan/

My Finance. "9 Types of Leadership Styles in Organizations Based on Theory

Naderi, N., \& Jadidi, L. (2014). The Study of the effects between Leadership Style, Organization Culture, Employees Performance on Leadership Performance (Case: Government Hospitals in Isfahan). International Journal of Academic Research in Business and Social Sciences, 4 (12). https://doi.org/10.6007/ijarbss/v4-i12/1338 
Njoroge, S. W., Kwasira, J., Wambui Njoroge, S., \& Kwasira, J. (2015). Influence of Compensation and Reward on Performance of Employees at Nakuru County Government. IOSR Journal of Business and ManagementVer. I, 17 (11), 2319-7668. https://doi.org/10.9790/487X-171118793

Nurcahyani, N., \& Adnyani, I. (2016). Effect Of Compensation And Motivation On Employee Performance With Work Satisfaction As Intervening Variables. E-Journal of Udayana University Management.

Paramitadewi, K. F. (2017). The influence of workload and compensation on the performance of the employees of the Tabanan Regency Secretariat. Journal of Management.

Rasmansyah, MM., (2017). Effect of Leadership Style and Compensation on Nurse Performance at Anna Hospital, Pekayon-Bekasi. Journal of Business Management Krisnadwipayana, 5 (3). https://doi.org/10.35137/jmbk.v5i3.159

Riana, N., Fajri, K., \& Alsysaumi, K. (2016). Effect of Compensation on Kampung Batu Malakasari Tektona the Effect of Compensation Through Employees' Performance At Batu Malakasari Tektona Village Waterpark. Tourism Scientific Journal, 2.

Saputri, N. (2017). Effect of Compensation and Leadership on Teacher Performance (Study at SMK Bina Patria 2 Sukoharjo). Diponegoro Journal of Management, 6, 2.

Setiawan, K., \& Mujiati, N. (2016). Influence Of Leadership And Compensation On Employee Performance Of Pt. Astra Honda Nusa Dua Badung District. E-Journal of Udayana University Management.

Sinambela, Lijan Poltak.2018. Human Resources Management Book 2018. Jakarta: Earth Literacy.

Tumilaar, B. R. (2015). THE EFFECT OF DISCIPLINE, LEADERSHIP, AND MOTIVATION ON EMPLOYEE PERFORMANCE AT BPJS EMERGENCY. Journal of Economic, Management, Business and Accounting Research.

Wijaya, T., \& Andreani, F. (2015). Effect of Motivation and Compensation on Employee Performance at Pt Sinar Jaya Abadi Bersama. Agora. 